\title{
What are the antecedents of women's entrepreneurial orientation?
}

\author{
Gina Santos $^{1,2}$ - Carla S. Marques ${ }^{1,2}$. \\ João J. M. Ferreira ${ }^{3,4}$ (D)
}

Published online: 21 November 2017

C) Springer Science+Business Media, LLC, part of Springer Nature 2017

\begin{abstract}
This study seeks to identify the antecedents of women's entrepreneurial orientation (EO) and exploring what possible relationships that may exist between them. The research focuses on women entrepreneurs and non-entrepreneurs in a quantitative perspective whose methodology consisted of the collection of primary data through a survey distributed to women in Portugal. After structural equation modelling was applied, the results suggested that recognition of opportunities influences EO. This influence is expressed both directly and indirectly through training in management and entrepreneurial skills. These findings led to the conclusion that policies promoting training for community members, in general, need to be rethought and policies need to emphasise training in management that enhances entrepreneurial skills, thereby increasing the proliferation of entrepreneurship. Entrepreneurship education and training should be promoted from basic education onwards in order to develop entrepreneurial skills from an early age. Prior to this study, the relationships between opportunity recognition, management training and entrepreneurial skills have never been studied in relation to women.
\end{abstract}

João J. M. Ferreira

jjmf@ubi.pt

Gina Santos

gina.santos@utad.pt

Carla S. Marques

smarques@utad.pt

1 Department of Economics, Sociology and Management, University of Trás-os-Montes e Alto Douro, Vila Real, Portugal

2 CETRAD - Research Unit, Vila Real, Portugal

3 Department of Business and Economics, University of Beira Interior, Covilhã, Portugal

4 NECE Research Unit, Covilhã, Portugal 
Keywords Women entrepreneurship - Entrepreneurial orientation · Opportunity recognition · Training and entrepreneurial skills

\section{Introduction}

Several studies have conducted contextualised research whose results have demonstrated the importance of studying female entrepreneurship (e.g., Greene et al. 1999; Carter et al. 2001; Brush et al. 2009, 2014; Holmquist and Carter 2009; Jennings and Brush 2013; Henry et al. 2015). This research has branched off from purely exploratory and descriptive studies, which were the first in this area (e.g., Greene et al. 1999; Hisrich and Brush 1984; Moore and Buttner 1997) to focus on the entrepreneurial process. The emphasis has been on what factors promote entrepreneurial intentions to create businesses and start-ups, but this field of study is beginning to examine the management of these companies, particularly the definition of strategies for companies' performance and competitiveness that can take into account the increased globalisation of markets (Carter and Marlow 2006; de Bruin et al. 2007; Brana 2013).

Women are one of the fastest growing categories of entrepreneurs worldwide, and they contribute significantly to employment, innovation and economic growth in all economic stages (Kelley et al. 2011). According to data from the Global Entrepreneurship Monitor (GEM) Women's Entrepreneurship 2016/17 Report, by 2016, an estimated 163 million women were starting or running new businesses in 74 economies around the world and an estimated 111 million were running established businesses. This not only shows the impact of women entrepreneurs across the globe, but highlights their contributions to the growth and well-being of their societies (Kelley et al. 2017).

According to data from the GEM (2017) on Portugal, the number of early-stage male entrepreneurs is $10.4 \%$ of the adult male population, and the number of earlystage female entrepreneurs is $6.1 \%$ of the adult female population. The cited report notes that $42.4 \%$ of Portuguese people think they have the knowledge, experience and skills necessary to start a business project. However, only $29.5 \%$ believed that good opportunities would arise to start a business where they lived, within six months of the survey. Thus, the data reveal that, in Portugal - as in the three types of economies considered in the GEM (2017) report (i.e. factor-efficiency and innovation-driven) individuals' perceptions of their capacity to create a business do not match their perceptions of opportunities to do so in the short term, which always downplay the latter (GEM 2017). Given the importance of opportunity recognition as a direct antecedent - or entrepreneurial skills and training in management as mediators - of EO, the present study seeks to fill a gap in research on this subject in the area of female entrepreneurship. Thus, this research aims to identify the antecedents of women's entrepreneurial orientation (EO) and exploring what possible relationships that may exist between them. The study was applied to women entrepreneurs and nonentrepreneurs in northern Portugal through a quantitative and empirical study whose methodology consisted of the collection of primary data using a questionnaire distributed to women in this region. It was followed the trend of research in the area, namely Ahl and Marlow (2012) and Henry et al. (2015) who invoke as central independent variable the male and female gender claiming that the focus of research 
on female entrepreneurship should be based on women entrepreneurs considering the field of entrepreneurship in general.

After the above introduction, the paper briefly discusses theoretical approaches to EO and its antecedents (i.e. opportunity recognition, training in management and entrepreneurial skills) with regard to women entrepreneurs. In section three, the methodology used is described. Next, the results are presented, and the last section discusses these, along with the study's limitations and implications.

\section{Related work}

Originally conceived by Miller (1983) and later extended by Covin and Slevin (1989, 1991), entrepreneurial orientation (EO) gradually emerged as a rigorously empirical concept that has helped to develop knowledge in the field of management (Basso et al. 2009). EO is considered by Wales et al. (2013) to be a key idea in the literature on corporate entrepreneurship, which includes discussions in magazines, books and the media. EO can refer to companies and individuals, and it can be an important feature of new or existing companies (Ferreira et al. 2016).

Kollman (2007) states that EO can be divided into five main aspects. First, individuals struggling for a high degree of autonomy are more likely to act in an entrepreneurial way. Second, individuals' attitude towards innovation determines their entrepreneurial behaviour. Third, risk propensity is likely to influence OE. Fourth, proactive individuals do not stop taking advantage of business opportunities that may arise. Last, competitive aggressiveness is similar to the need for self-realisation, which also influences OE. After more than 30 years of academic research, EO is commonly held to reflect a general stance that consists of deeply rooted beliefs and values associated with a tendency to be both proactive, risk-taking and innovative (Rauch et al. 2009; Ferreira et al. 2017). The present study was based on the construct EO used in several studies and based in the work of Bolton and Lane (2012), as well as following Miller's (1983) conceptualisation of EO by focusing on innovation, risk-taking and proactivity.

According to Goktan and Gupta (2015), gender - as an influential aspect of individuals' self-perception - plays a significant role in men and women's orientation towards entrepreneurship. For the cited authors, both a male and female identity, when encouraged, are prone to entrepreneurship, but the determinant factor of EO is an androgynous identity, which places an equal emphasis on masculinity and femininity. Focusing on the differences between men and women's EO, some studies (e.g., Anna et al. 2000; Gundry and Welsch 2001) have found that women's enterprises, in general, present a lower level of innovation given their smaller size, location in traditional industries with low innovation rates and restricted access to resources. Other studies (e.g., Manolova et al. 2007) have also revealed that this lower level of innovation is due to the lack of human capital, such as education, experience or experienced founders. Concerning proactivity, Gupta and Bhawe (2007) show that women's entrepreneurial intentions may decrease when they are exposed to stereotypes about entrepreneurs being male. According to Lim and Envick's (2013) comparative analysis of studies on the proactivity of men and women in different cultural contexts, men are more proactive than women when they face entrepreneurial opportunities. As for risk-taking, some differences exist between men and women, with women generally looking for 
more familiar solutions in traditional industries (Anna et al. 2000) with fewer risks (Lim and Envick 2013). This is corroborated, for example, by Minniti and Nardone (2007), inferring that two decisive factors limiting women's propensity to start a business are the fear of failure and the inability to identify opportunities.

\section{Antecedents of women's EO}

For Shane and Venkataraman (2000), the two fundamental questions that stand out in research on entrepreneurship are why some individuals are more likely to recognise entrepreneurial opportunities and why some individuals more likely to exploit these opportunities. Over the years, numerous researchers have sought to answer these questions, developing studies based on several characteristics. These include demographic (e.g., experience in some area), behavioural (e.g. management style), psychological and/or personality (e.g. risk propensity) and cognitive traits (e.g. entrepreneurial alertness) (e.g. Hornaday and Aboud 1971; Busenitz and Barney 1997; Miner 2000; Shane and Venkataraman 2000; Gaglio and Katz 2001). The present study focused on background factors for EO, namely, opportunity recognition, entrepreneurial skills and training in management.

\section{Opportunity recognition}

According to Langowitz and Minniti (2007), a growing number of researchers agree that opportunity recognition represents the most distinctive and fundamental entrepreneurial behaviour (e.g., Shane and Venkataraman 2000). Entrepreneurs are individuals who are more likely than others to be on the alert to identify and exploit profit opportunities (Kirzner 1973). Entrepreneurial opportunities play a central role in the literature on entrepreneurship, and they are understood as positive and favourable circumstances for entrepreneurial actions (e.g., Shane et al. 2010). This concept is fundamental to recent entrepreneurship frameworks, such as those presented by Shane and Venkataraman (2000), Gaglio and Katz (2001), Hsieh et al. (2007), Murphy (2011) and Gupta et al. (2014). According to Arentz et al. (2013), who based their research on Kirzner's (1973) work, research on entrepreneurship from the perspective of alertness has made important contributions to both the origin and identification of entrepreneurial opportunities.

In general, opportunities arise from changes in the environment in which individuals operate. These changes create an imbalance, which individuals can exploit (e.g., Holcombe 2003). Recognising these opportunities may create positive and favourable circumstances that lead to entrepreneurial actions. The questions that have driven research on entrepreneurial opportunities are how, when and why some individuals can recognise opportunities while others cannot (Venkataraman 1997). Several researchers from different fields have attempted to address this issue, leading to a significant expansion of findings in this area (e.g., Baron and Ensley 2006; Grégoire et al. 2010). Several prominent factors that play an essential role in the recognition of entrepreneurial opportunities have emerged in the last three decades. Some examples of these factors are human and social capital (DeTienne and Chandler 2007; RamosRodríguez et al. 2010), individual traits (e.g., Zahra et al. 2006) and various degrees of alertness (Gaglio and Katz 2001). Studies have shown that one or more factors 
influence individuals' ability to recognise opportunities (e.g., Cliff et al. 2006). Therefore, studying these factors promotes a deeper understanding of what triggers the process of entrepreneurial recognition and explains in more detail why some individuals can recognise opportunities and others cannot (Baron 2006).

The cognitive approach to these questions has its roots in psychology and sociology (see e.g., Shane and Venkataraman 2000; Gaglio and Katz 2001; Sánchez et al. 2011). Psychologists have shown that individuals' internal attributes, such as the need for achievement, locus of control, ambiguity tolerance, emotional stability, and risk propensity, are stable and differ from person to person. Studies have further revealed that differences in psychological profiles determine why some individuals recognise entrepreneurial opportunities and behave differently in response to these opportunities. These psychological attributes, which enhance opportunity recognition, are also related to EO (Begley and Boyd 1987; Miner 2000), which is defined as a person's willingness to take on the risks associated with starting new business (Zahra et al. 2005). Thus, in comparison to non-founders, business founders have higher scores on risk propensity and ambiguity tolerance (Begley and Boyd 1987). These results help explain why certain individuals may discover and pursue certain business opportunities, as well as their proactiveness in exploiting those opportunities. Kollmann et al. (2007) state that the entrepreneur's important individualised role becomes clear when he or she recognises a business opportunity and decides to exploit it. Thus, individuals at the beginning of the entrepreneurial process can differentiate themselves from others by a set of emotions, cognitions and patterns of innate behaviour. The identification of opportunities and the skills that entrepreneurs possess can influence their EO. Therefore, the following research hypotheses were formulated for the present study:

$\boldsymbol{H}_{\boldsymbol{1}}$ : Opportunity recognition increases (1.e. improves and strengthens) women's EO.

$\mathrm{H}_{2}$ : Opportunity recognition increases women's $E O$, mediated by entrepreneurial skills and training in management.

$\boldsymbol{H}_{3}$ : Opportunity recognition increases entrepreneurial skills.

\section{Entrepreneurial skills}

According to Adeyemo (2009), one basic ability is the way individuals adjust to life. However, capacity is a quality of performance that does not depend fundamentally on a person's innate capacity but that needs to be developed through training, practice and experience. Entrepreneurial skills are the necessary basic skills that allow individuals to start and develop a financially successful business. Liñán (2008) argues that, for entrepreneurs to be successful, they must develop certain skills and abilities such as leadership and communication, innovation, networking, creativity and problem solving.

Regarding capabilities and their relationship to EO, several studies have established causal relationships between these two dimensions (e.g., Engelen et al. 2015; Muchiri and McMurray 2015). Researchers have emphasised communication and networking since entrepreneurs, according to Ripollés and Blesa (2005), use their interpersonal and inter-organisational relationships to gain access to relevant information, advice and, in 
some cases, solutions to problems. In addition, Martins (2016) states that the use of interpersonal relationships between entrepreneurs and their organisations' networks can strengthen characteristics associated with EO such as innovation, proactivity and risk propensity. Hence, the following research hypothesis was postulated in the present study:

\section{$\boldsymbol{H}_{4}$ : Entrepreneurial skills strengthen women's $E O$.}

\section{Training in management}

Training in management is considered to be a fundamental factor, with several researchers arguing that people who attend entrepreneurship courses have greater entrepreneurial intent or, at least, an increase in their belief in their entrepreneurship skills (e.g., Wilson et al. 2007; Sánchez 2013). According to Fayolle and Klandt (2006), management education - especially entrepreneurship education - is not only about knowing how to start a business but also about developing entrepreneurial skills and attitudes. Some authors (e.g., Wilson et al. 2007; Brush et al. 2014) report that, once women gain entrepreneurial skills, they can develop their business with greater confidence based on these skills.

Taylor (1996) argues that individuals, when considering employment options, are likely to be constrained by previous education, training or work experience, and, thus, they will focus on the opportunities of a sector suited to their abilities. Carter et al. (2001) found that some studies have highlighted a lack of professional experience and training in management as a difference between entrepreneurial men and women. Since women entrepreneurs tend to have less experience and training than male entrepreneurs (Hundley 2001), their family may necessarily serve as a training ground, preparing these women to interact with employees and clients and use planning skills and motivational techniques (e.g.. Gundry and Welsch 2001). In their family roles, women can develop unique approaches to leadership, network formation and conflict resolution (Brush 1992; Buttner 2001). For example, managers have reported that parenting and developing strong personal relationships taught them to understand, motivate and manage employees (Ruderman et al. 2002). In short, the self-perception of having the necessary skills and training is an important factor in determining entrepreneurial participation, independently of other contextual variables including gender (DíazGarcía and Jiménez-Moreno 2010). Hence, the following research hypotheses were formulated in the present study:

$\boldsymbol{H}_{5}$ : Opportunity recognition predicts women's training in management.

$\boldsymbol{H}_{\boldsymbol{6}}$ : Management training increases women's EO.

\section{Conceptual research model}

Based on the study's aims and the research hypotheses based on the literature, the conceptual research model shown in Fig. 1 was developed. This model was based on the articulation and incorporation of dimensions addressed in the following studies: 1) 


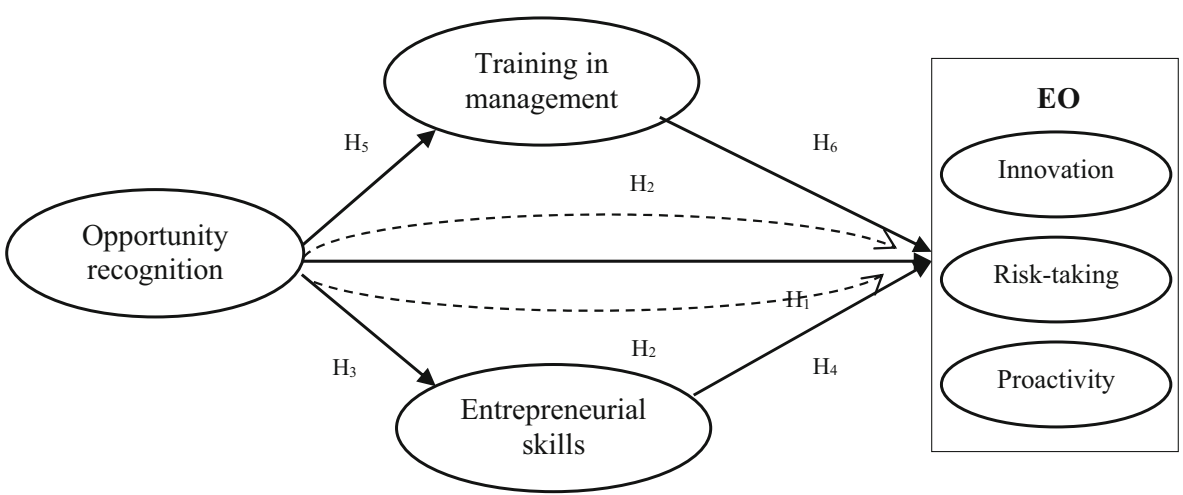

Fig. 1 Conceptual research model

Zahra et al. (2005) - opportunity recognition, 2) Liñán (2008) - entrepreneurial skills and 3) Bolton and Lane (2012) -EO.

\section{Methodology}

This study sought to identify and explore the possible relationships between opportunity recognition, management training and entrepreneurial skills as potential antecedents of women's EO. The research focused on women entrepreneurs and nonentrepreneurs in northern Portugal. This quantitative and empirical study collected primary data through a questionnaire distributed to women in northern Portugal in 2016. Data collection used a sample intentionally. The survey consisted of 1) sociodemographic questions; 2) questions evaluating EO, consisting of 10 items subdivided into three dimensions: innovation, risk-taking and proactivity (Bolton and Lane 2012); 3) a section of three items that assessed respondents' entrepreneurial skills (Liñán 2008); 4) another set of questions evaluating training in management, consisting of eight items; and 5) two questions assessing opportunity recognition (Zahra et al. 2005). All questions were answered on a five-point Likert-type scale.

The sample consisted of 100 women from the north of Portugal, aged between 18 and 65 years old, with a mean of 35.98 years $(\mathrm{SD}=9.94)$. A full $95 \%$ of these women have Portuguese nationality, and they reside mainly in the region under study. Regarding their education, $73 \%$ of respondents have higher education qualifications; it's similar with the results express in the Women's Entrepreneurship 2016/17 GEM Report, which states that innovation-oriented countries average $61 \%$ women entrepreneurs with higher education and specialized training. Half of this women's were employed, $22 \%$ were unemployed and $13 \%$ were women entrepreneurs.

The psychometric properties of the EO construct and its dimensions of innovation, risk-taking and proactivity were tested using confirmatory factorial analysis. The results showed that the EO construct is a second-order reflective model with the aforementioned dimensions, so the respective structural coefficients were evaluated. Since the results were virtually the same, the second-order model of EO and the magnitude of the respective structural coefficients were confirmed together with the analysis of the proposed model - to avoid redundancy and duplication in their exposure. 
The proposed structural model was estimated through partial least squares structural equation modelling (PLS-SEM) (Hair Jr et al. 2016), using the SmartPLS 3.0 software (Ringle et al. 2015). In the analysis of the measurement model, the analysis began with presenting some of its properties and definitions adopted. Thus, the path weighting scheme was adopted in the PLS algorithm. The initial values for the relationships of the measurement model were 1 , and the data were standardised with a mean of 0 and a variance of 1, a maximum number of 300 iterations and the abort criterion of 1.0E-7. Since the evaluation of SEM-PLS-based models relies on bootstrapping - a form of resampling procedure - a number of cases equal to the present sample (i.e. 100) were used as bootstrapping configurations, with 5000 replications and changes at the individual level.

\section{Results}

\section{Outer model}

The measurement model was initially assessed with respect to the first-order latent variables (i.e. dimensions of EO, entrepreneurial skills, training in management and recognition of opportunities), in order to follow Hair et al. (2012) and Hair et al.'s (2013) recommendations. This process evaluated the reliability of the indicators (Hulland 1999), factor validity or reliability of internal consistency and convergent validity (Bagozzi and Yi 1988).

The analyses confirmed a composite reliability (CR) with values ranging from 0.767 to 0.869 (i.e. more than 0.70 ), thus ensuring construct reliability or internal consistency (Fornell and Larcker 1981). In PLS-SEM, if the standardised factorial values of all items are greater than or equal to 0.7 , the factors are usually assumed to have factorial validity (Hair et al. 2011). All items of the various dimensions presented factorial weights that oscillated between 0.669 and 0.853 , thus verifying factorial validity. In addition, variance extracted mean (VEM) values of more than 0.5 are indicative of adequate convergent validity. The VEM values produced are 0.524 for risk-taking, 0.623 for innovation and 0.647 for proactivity and, thus, greater than 0.50 . Therefore, convergent validity was confirmed (Bagozzi and Yi 1988).

Regarding the second-order latent variable (i.e. EO), the present analyses also followed Hair et al. (2012) and Hair et al.'s (2013) recommendations, evaluating the construct reliability, regression coefficients, factorial validity, convergent validity and discriminant validity. As shown in Table 1, a CR value of 0.861 (i.e. more than 0.70 ) was calculated,

Table 1 Composite reliability (CR) and validity of the second-order latent variable (EO)

\begin{tabular}{llll}
\hline Construct & Regression coefficients & AVE & CR \\
\hline Innovation & $0.919^{* * * *}$ & 0.677 & 0.861 \\
Risk-taking & $0.679^{* * * *}$ & & \\
Proactivity & $0.851^{* * * *}$ & & \\
\hline
\end{tabular}

**** $p<0.001$ 
thereby ensuring construct reliability. Factorial validity was measured by analysing the regression coefficients, which oscillate between 0.679 for risk-taking and 0.919 for innovation, and, as a result, confirm factorial validity (Hair et al. 2011). The convergent validity was evaluated by determining the value of the VEM, which was 0.677 (i.e. more than 0.50), so convergent validity was also confirmed (Bagozzi and Yi 1988).

To determine the discriminant validity of the present construct, the AVE values of any two constructs were compared with the square of the correlation between these factors. The square root values of the factors' AVE need to be higher than the correlation between them, which was confirmed for the second-order EO construct (see Table 2).

Table 3 presents the FC and VEM values for the remaining first-order dimensions of the model (i.e. entrepreneurial skills, training in management and recognition of opportunities), with FC values ranging from 0.802 to 0.925 ( $>0.70)$. In this way, the construct reliability or internal consistency of the items of the various dimensions present factorial weights that oscillate between 0.641 and 0.884 , thus verifying factorial validity. In addition, the VEM values range between 0.576 and 0.728 (>0.50), therefore convergent validity was assured (Bagozzi and Yi 1988).

\section{Inner model}

SEM-PLS does not report any type of index, such as the comparative fit index or root mean square error of approximation used in covariance-based SEM. Instead, the evaluation of the PLS model is based on nonparametric predictive measures (Chin 1998). The structural model is evaluated mainly by the R-squared $\left(\mathrm{R}^{2}\right)$ of the latent endogenous variable (Chin 1998), as well as by the effect size $\left(f^{2}\right)$ (Cohen 1988). The model's predictive capacity was analysed through the $\mathrm{R}^{2}$ of the model's endogenous variables. The EO $\mathrm{R}^{2}$ value is 0.329 , while training in management is 0.111 and entrepreneurial skills 0.104 , thereby confirming that all are above the acceptable cutoff point of 0.1 . The $f^{2}$ complements the $\mathrm{R}^{2}$ and considers the relative impact of a particular exogenous variable on an endogenous variable through changes in the $\mathrm{R}^{2}$ (Cohen 1988). Cohen (1988) suggests $f^{2}$ values of $0.02,0.15$ and 0.35 for small, medium and large effects of predictive variables (see Table 4).

\section{Discussion}

The hypotheses were tested by analysing the values of the regression coefficients and the respective $t$-test as an indicator of their significance. To produce more reasonable

Table 2 Correlations and discriminant validity of the second-order latent construct (EO)

\begin{tabular}{llll}
\hline & Innovation & Risk-taking & Pro-activity \\
\hline Innovation & $\mathbf{0 . 7 8 9}$ & & \\
Risk-taking & 0.637 & $\mathbf{0 . 7 2 4}$ & \\
Proactivity & 0.775 & 0.614 & $\mathbf{0 . 8 0 4}$ \\
\hline
\end{tabular}

Square root values of the AVE are on the diagonal 
Table 3 Composite reliability (CR) and validity of the other first-order dimensions of the model

\begin{tabular}{llr}
\hline Construct & AVE & CR \\
\hline Entrepreneurial skills & 0.576 & 0.802 \\
Training in management & 0.609 & 0.925 \\
Recognition of opportunities & 0.728 & 0.843 \\
\hline
\end{tabular}

estimates of standard errors, a bootstrapping procedure was used (Tenenhaus et al. 2005). Figure 2 presents the structural model, and Table 5 summarises the results for the hypotheses tested.

As the evaluation of the structural model showed, opportunity recognition influences EO (see Table 5). This influence is expressed in a direct way $(\beta=$ $0.390, \mathrm{p}<0.001)$, giving support to Hypothesis 1 , and in an indirect way $(\beta=$ $0.116 ; p=0.009$ ), that is, mediated by training in management (Begley and Boyd 1987; Miner 2000), so this effect is defined as the willingness of a person to take the risks associated with setting up new businesses and exploiting these opportunities (Zahra et al. 2005). Notably, this influence can be mediated by both training in management and entrepreneurial skills (i.e. Hypothesis 2). In addition, opportunity recognition has a significant influence on entrepreneurial skills $(\beta=0.323 ; \mathrm{p}<0.001)$, and these, in turn, influence EO ( $\beta=0.161 ; p=0.048$ ), thus supporting Hypotheses 3 and 4 (Muchiri and McMurray 2015; Engelen et al. 2015). Leadership and communication skills and a capacity for making professional contacts, forming network and developing new products and services predict EO among the women in the present sample.

As for the connection between opportunity recognition and training in management, the results confirm an influence exists $(\beta=0.333, p<0.001)$, which supports Hypothesis 5 . The analyses also verified, in a more moderate way, that training in management ( $\beta=0.193 ; p=0.025$ ) impacts EO, thereby confirming Hypothesis 6 (Wilson et al. 2007; Brush et al. 2014). Thus, the frequency of training in management, namely, in business strategy, accounting and financial management, tax and labour legislation, logistics, marketing, human resources and sales and/or market analysis, has a positive influence on EO.

Table 4 Effect sizes of predictor variables on endogenous variables

\begin{tabular}{llll}
\hline Path & $\mathrm{R}^{2}$ & $f^{2}$ & Effect of $f^{2}$ \\
\hline Opportunity recognition $\rightarrow$ EO & 0.329 & 0.191 & Medium \\
Opportunity recognition $\rightarrow$ entrepreneurial skills & 0.111 & 0.116 & Small \\
Opportunity recognition $\rightarrow$ training in management & 0.104 & 0.125 & Small \\
Entrepreneurial skills $\rightarrow$ EO & 0.329 & 0.031 & Small \\
Training in management $\rightarrow$ EO & 0.329 & 0.045 & Small \\
\hline
\end{tabular}




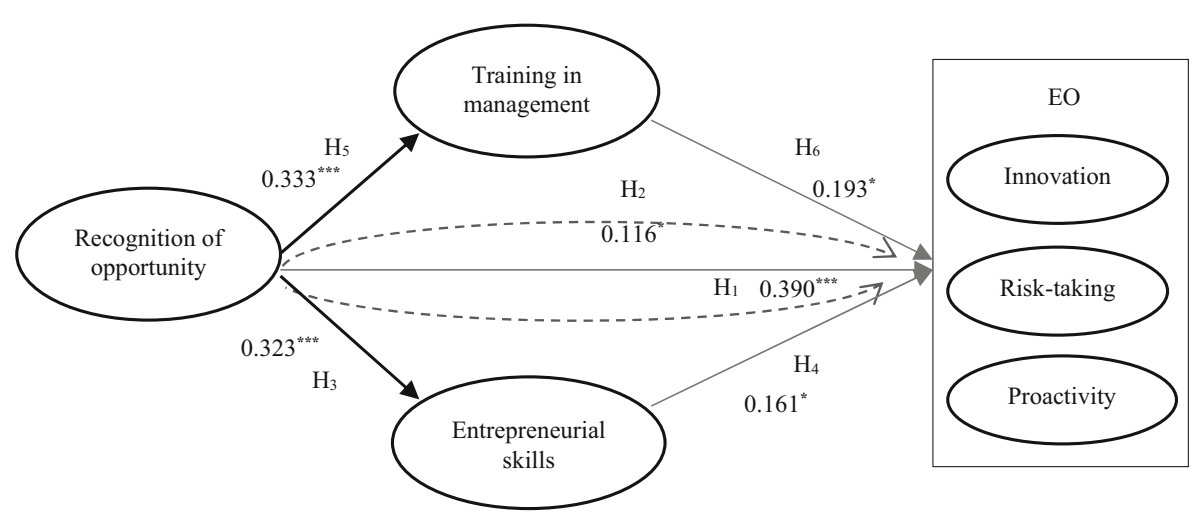

Fig. 2 Evaluation of the structural model. Notes: ${ }^{* * * *} p<0.001 ;{ }^{*} 0.01<p<0.05$

\section{Conclusion and managerial implications}

The results of the present study suggest that opportunity recognition influences EO, which translates this effect both directly and indirectly, that is, mediated by training in management and entrepreneurial skills. Although opportunity recognition in terms of entrepreneurship in general has been widely studied, this relationship had not previously been studied with a research population of entrepreneurial women. The current research is thus a direct response to Jennings and Brush's (2013) call for studies on entrepreneurship to be specifically applied to women. Recognising opportunities is extremely important not only in innovation-driven economies but also in projects targeting the factors of production and efficiency in order to expand entrepreneurship and different countries' economies.

Regarding implications for training, the proposed model is of central importance, revealing that policies promoting training for community members, in general, need to be rethought because training in management, in particular, enhances entrepreneurial skills by increasing the proliferation of entrepreneurship. This, in turn, can support the creation of self-employment, which is a key factor in economic development. The teaching of entrepreneurship should also be promoted from basic education onwards to

Table 5 Analysis of hypotheses under study

\begin{tabular}{|c|c|c|c|}
\hline Pathway & $\begin{array}{l}\text { Standardised regression } \\
\text { coefficient }\end{array}$ & $p$ & $\begin{array}{l}\text { Hypothesis } \\
\text { supported? }\end{array}$ \\
\hline $\mathrm{H}_{1}$ : Opportunity recognition $\rightarrow$ EO & $0.390^{* * * *}$ & $<0.001$ & yes \\
\hline $\mathrm{H}_{2}$ : Opportunity recognition $\rightarrow$ EO (mediated) & $0.116^{*}$ & 0.009 & Yes \\
\hline $\mathrm{H}_{3}$ : Opportunity recognition $\rightarrow$ entrepreneurial skills & $0.323^{* * * *}$ & $<0.001$ & Yes \\
\hline $\mathrm{H}_{4}:$ Entrepreneurial skills $\rightarrow$ EO & $0.161^{*}$ & 0.048 & Yes \\
\hline $\mathrm{H}_{5}$ : Opportunity recognition $\rightarrow$ training in management & $0.333^{* * * *}$ & $<0.001$ & Yes \\
\hline $\mathrm{H}_{6}:$ Training in management $\rightarrow \mathrm{EO}$ & $0.193^{*}$ & 0.025 & Yes \\
\hline
\end{tabular}

**** $\mathrm{p}<0.001 ; * 0.01<\mathrm{p}<0.05$ 
develop entrepreneurial skills from an early age. This is already a recommendation of the European Union, but most southern European countries still do not focus on implementing entrepreneurship education in the early years, with only a few pilot projects having been developed with no further follow-up. Regarding this study's limitations, the sample size needs to be emphasised, as it could be more representative and geographically broader. Thus, this research should be replicated in other regions of Portugal and elsewhere, taking into account cultural differences, stages of economic and social development and issues such as religion and ethnicity.

\section{References}

Adeyemo, S. A. (2009). Understanding and acquisition of entrepreneurial skills: a pedagogical re-orientation for classroom teachers in science education. Journal of Turkish Science Education, 6(3), 57.

Anna, A. L., Chandler, G. N., Jansen, E., \& Mero, N. P. (2000). Women business owners in traditional and non-traditional industries. Journal of Business Venturing, 15(3), 279-303. https://doi.org/10.1016/S08839026(98)00012-3.

Ahl, H., \& Marlow, S. (2012). Exploring the dynamics of gender, feminism and entrepreneurship: advancing debate to escape a dead end? Organization, 19(5), 543-562. https://doi.org/10.1177/1350508412448695.

Arentz, J., Sautet, F., \& Storr, V. (2013). Prior-knowledge and opportunity identification. Small Business Economics, 41(2), 461-478. https://doi.org/10.1007/s11187-012-9437-9.

Bagozzi, R. P., \& Yi, Y. (1988). On the evaluation of structural equation models. Journal of the Academy of Marketing Science, 16(1), 74-94. https://doi.org/10.1007/BF02723327.

Baron, R. A. (2006). Opportunity recognition as pattern recognition: how entrepreneurs 'connect the dots' to identify new business opportunities. The Academy of Management Perspectives, 20(1), 104-119. https://doi.org/10.5465/AMP.2006.19873412.

Baron, R. A., \& Ensley, M. D. (2006). Opportunity recognition as the detection of meaningful patterns: evidence from comparisons of novice and experienced entrepreneurs. Management Science, 52(9), 13311344. https://doi.org/10.1287/mnsc.1060.0538.

Basso, O., Fayolle, A., \& Bouchard, V. (2009). Entrepreneurial orientation: the making of a concept. The International Journal of Entrepreneurship and Innovation, 10(4), 313-321. https://doi.org/10.5367 /000000009790012327.

Begley, T. M., \& Boyd, D. P. (1987). A comparison of entrepreneurs and managers of small business firms. Journal of Management, 13(1), 99-108. https://doi.org/10.1177/014920638701300108.

Bolton, D., \& Lane, M. D. (2012). Individual entrepreneurial orientation: development of a measurement instrument. Education + Training, 54(2-3), 219-233.

Brana, S. (2013). Microcredit: an answer to the gender problem in funding? Small Business Economics, 40(1), 87-100. https://doi.org/10.1007/s11187-011-9346-3.

Brush, C., de Bruin, A., \& Welter, F. (2009). A gender-aware framework for women's entrepreneurship. International Journal of Gender and Entrepreneurship, 1(1), 8-24. https://doi.org/10.1108 /17566260910942318.

Brush, C. G. (1992). Research on women business owners: past trends, a new perspective and future directions. Entrepreneurship, Theory and Practice, 16(4), 5-30.

Brush, C. G., de Bruin, A., \& Welter, F. (2014). Advancing theory development in venture creation: signposts for understanding gender. In K. V. Lewis, C. Henry, E. J. Gatewood, \& J. Watson (Eds.), Women's entrepreneurship in the 21st century: an international multi-level research analysis (pp. 11-26). Cheltenham: Edward Elgar Publishing.

Busenitz, L. W., \& Barney, J. B. (1997). Differences between entrepreneurs and managers in large organizations: biases and heuristics in strategic decision-making. Journal of Business Venturing, 12(1), 9-30. https://doi.org/10.1016/S0883-9026(96)00003-1.

Buttner, E. H. (2001). Examine female entrepreneurs' management style: an application of a relational frame. Journal of Business Ethics, 29(3), 253-269. https://doi.org/10.1023/A:1026460615436.

Carter, S., \& Marlow, S. (2006). Female entrepreneurship: empirical evidence and theoretical perspectives. In N. Carter, C. Henry, B. O'Cinniede, \& K. Johnston (Eds.), Female entrepreneurship: implications for education, training and policy (pp. 11-36). London: Routledge. 
Carter, S., Anderson, S. \& Shaw, E. (2001). Women's business ownership: a review of the academic, popular and internet literature. [online] University of Strathclyde, https://www.researchgate. net/publication/237222197_Women's_Business_Ownership_A_Review_of_the_Academic_Popular_ and_Internet_Literature.

Chin, W. W. (1998). The partial least squares approach to structural equation modeling. In G. A. Marcoulides (Ed.), Modern methods for business research. New Jersey: Lawrence Erlbaum Associates.

Cliff, J. E., Jennings, P. D., \& Greenwood, R. (2006). New to the game and questioning the rules: the experiences and beliefs of founders who start imitative versus innovative firms. Journal of Business Venturing, 21(5), 633-663. https://doi.org/10.1016/j.jbusvent.2005.02.010.

Cohen, J. (1988). Statistical power analysis for the behavioral sciences. New Jersey: Lawrence Erlbaum Associates.

Covin, J. G., \& Slevin, D. P. (1989). Strategic management of small firms in hostile and benign environments. Strategic Management Journal, 10(1), 75-87. https://doi.org/10.1002/smj.4250100107.

Covin, J. G., \& Slevin, D. P. (1991). A conceptual model of entrepreneurship as firm behavior. Entrepreneurship Theory and Practice, 16(1), 7-25.

de Bruin, A., Brush, C. G., \& Welter, F. (2007). Advancing a framework for coherent research on Women's entrepreneurship. Entrepreneurship Theory and Practice, 31, 323-339.

DeTienne, D. R., \& Chandler, G. N. (2007). The role of gender in opportunity identification. Entrepreneurship Theory and Practice, 31(3), 365-386.

Díaz-García, M. C., \& Jiménez-Moreno, J. (2010). Entrepreneurial intention: the role of gender. International Entrepreneurship and Management Journal, 6(3), 261-283. https://doi.org/10.1007/s11365-008-0103-2.

Engelen, A., Gupta, V., Strenger, L., \& Brettel, M. (2015). Entrepreneurial orientation, firm performance, and the moderating role of transformational leadership behaviors. Journal of Management, 41(4), 1069-1097. https://doi.org/10.1177/0149206312455244.

Fayolle, A., \& Klandt, H. (2006). International entrepreneurship education: issues and newness. Cheltenham: Edward Elgar Publishing. https://doi.org/10.4337/9781847201652.

Ferreira, F. A., Marques, C. S., Bento, P., Ferreira, J. J., \& Jalali, M. S. (2016). Operationalizing and measuring individual entrepreneurial orientation using cognitive mapping and MCDA techniques. Journal of Business Research, 68(12), 2691-2702.

Ferreira, F. A. F., Jalali, M. S., Bento, P., Marques, C. S., \& Ferreira, J. J. (2017). Enhancing individual entrepreneurial orientation measurement using a metacognitive decision making-based framework. International Entrepreneurship and Management Journal, 13(2), 327-346. https://doi.org/10.1007 /s11365-016-0388-5.

Fornell, C., \& Larcker, D. F. (1981). Evaluating structural equation models with unobservable variables and measurement error. Journal of Marketing Research, 18(1), 39-50. https://doi.org/10.2307/3151312.

Gaglio, C. M., \& Katz, J. A. (2001). The psychological basis of opportunity identification: entrepreneurial alertness. Small Business Economics, 16(2), 95-111. https://doi.org/10.1023/A:1011132102464.

Global Entrepreneurship Monitor (2017). GEM 2016/2017 - Global Report 2016/17. Global Entrepreneurship Monitor, [online], http://www.gemconsortium.org/.

Goktan, A. B., \& Gupta, V. K. (2015). Sex, gender, and individual entrepreneurial orientation: evidence from four countries. International Entrepreneurship and Management Journal, 11(1), 95-112. https://doi. org/10.1007/s11365-013-0278-z.

Greene, P., Brush, C., Hart, M., \& Saparito, P. (1999). Exploration of the venture capital industry: is gender an issue. In W. Bygrave et al. (Eds.), Frontiers of entrepreneurship research 1999: proceedings of the 19th annual entrepreneurship research conference (pp. 168-181). Babson Park: Babson College.

Grégoire, D. A., Barr, P. S., \& Shepherd, D. A. (2010). Cognitive processes of opportunity recognition: the role of structural alignment. Organization Science, 21(2), 413-431. https://doi.org/10.1287 /orsc.1090.0462.

Gundry, L. K., \& Welsch, H. P. (2001). The ambitious entrepreneur: high growth strategies of women-owned enterprises. Journal of Business Venturing, 16(5), 453-470. https://doi.org/10.1016/S0883-9026(99 )00059-2.

Gupta, V. K., \& Bhawe, N. M. (2007). The influence of proactive personality and stereotype threat on women's entrepreneurial intentions. Journal of Leadership \& Organizational Studies, 13(4), 73-85. https://doi.org/10.1177/10717919070130040901.

Gupta, V. K., Goktan, A. B., \& Gunay, G. (2014). Gender differences in evaluation of new business opportunity: a stereotype threat perspective. Journal of Business Venturing, 29(2), 273-288. https://doi. org/10.1016/j.jbusvent.2013.02.002.

Hair Jr, J. F., Hult, G. T. M., Ringle, C., \& Sarstedt, M. (2016). A primer on partial least squares structural equation modeling (PLS-SEM). Thousand Oaks: Sage Publications. 
Hair, J. F., Ringle, C. M., \& Sarstedt, M. (2011). PLS-SEM: indeed a silver bullet. Journal of Marketing Theory and Practice, 19(2), 139-151. https://doi.org/10.2753/MTP1069-6679190202.

Hair, J. F., Sarstedt, M., Ringle, C. M., \& Mena, J. (2012). An assessment of the use of partial least squares structural equation modeling in marketing research. Journal of the Academy of Marketing Science, 40(3), 414 433. https://doi.org/10.1007/s11747-011-0261-6.

Hair, J. F., Sarstedt, M., Ringle, C. M., \& Pieper, T. (2013). The use of partial least squares structural equation modeling in strategic management research: a review of past practices and future applications. Long Range Planning, 45(5-6), 320-340.

Henry, C., Foss, L. \& Ahl, H. (2015). Gender and entrepreneurship research: a review of methodological approaches. International Small Business Journal. [online] http://journals.sagepub.com/doi/abs/10.1177 /0266242614549779? journalCode=isbb.

Hisrich, R., \& Brush, C. (1984). The woman entrepreneur: management skills and business problems. Journal of Small Business Management, 22(1), 30-37.

Holcombe, R. G. (2003). The origins of entrepreneurial opportunities. The Review of Austrian Economics, 16(1), 25-43. https://doi.org/10.1023/A:1022953123111.

Holmquist, C., \& Carter, S. (2009). The Diana project: pioneering women studying pioneering women. Small Business Economics, 32(2), 121-128. https://doi.org/10.1007/s11187-008-9151-9.

Hornaday, J. A., \& Aboud, J. (1971). Characteristics of successful entrepreneurs. Personnel Psychology, 24, $141-153$.

Hsieh, C., Nickerson, J. A., \& Zenger, T. R. (2007). Opportunity discovery, problem solving and a theory of the entrepreneurial firm. Journal of Management Studies, 44(7), 1255-1277. https://doi.org/10.1111 j.1467-6486.2007.00725.x.

Hulland, J. (1999). Use of partial least squares (PLS) in strategic management research: a review of four recent studies. Strategic Management Journal, 20(2), 195-204. https://doi.org/10.1002/(SICI)1097-0266 (199902)20:2<195::AID-SMJ13>3.0.CO;2-7.

Hundley, G. (2001). What and when are the self-employed more satisfied with their work? Industrial Relations, 40(2), 293-316.

Jennings, J., \& Brush, C. (2013). Research on women entrepreneurs: challenges to (and from) the broader entrepreneurship literature. Academy of Management Annals, 7(1), 663-715. https://doi.org/10.1080 $/ 19416520.2013 .782190$.

Kelley, D., Brush, C., Greene, P., \& Litovsky, Y. (2011). The global entrepreneurship monitor 2010 women's report. Wellesley: Babson College.

Kelley, D., et al. (2017). The global entrepreneurship monitor women's entrepreneurship 2016717 report. Babson: Global Entrepreneurship Research Association (GERA).

Kirzner, I. (1973). Perception, opportunity, and profit: studies in the theory of entrepreneurship. Chicago: University of Chicago Press.

Kollman, K. (2007). Same-sex unions: the globalization of an idea. International Studies Quarterly, 51(2), 329-357. https://doi.org/10.1111/j.1468-2478.2007.00454.x.

Kollmann, T., Christofor, J., \& Kuckertz, A. (2007). Explaining individual entrepreneurial orientation: conceptualisation of a cross-cultural research framework. International Journal of Entrepreneurship and Small Business, 4(3), 325-340. https://doi.org/10.1504/IJESB.2007.013255.

Langowitz, N., \& Minniti, M. (2007). The entrepreneurial propensity of women. Entrepreneurship Theory and Practice, 31(3), 341-364.

Lim, S., \& Envick, B. R. (2013). Gender and entrepreneurial orientation: a multi-country study. International Entrepreneurship and Management Journal, 9(3), 465-482. https://doi.org/10.1007/s11365-011-0183-2.

Liñán, F. (2008). Skill and value perceptions: how do they affect entrepreneurial intentions? International Entrepreneurship and Management Journal, 4(3), 257-272. https://doi.org/10.1007/s11365-008-0093-0.

Manolova, T., Varter, N. M., Manev, I. M., \& Gyoshev, B. S. (2007). The differential effect of men and women entrepreneurs' human capital and networking on growth expectancies in Bulgaria. Entrepreneurship, Theory \& Practice, 31(3), 407-426.

Martins, I. (2016). Network usage, entrepreneurial orientation and their effectiveness on SMEs growth. The Journal of Entrepreneurship, 25(1), 18-41. https://doi.org/10.1177/0971355715616230.

Miller, D. (1983). The correlates of entrepreneurship in three types of firms. Management Science, 29(7), 770791. https://doi.org/10.1287/mnsc.29.7.770.

Miner, J. B. (2000). Testing a psychological typology of entrepreneurship using business founders. The Journal of Applied Behavioral Science, 36(1), 43-69. https://doi.org/10.1177/0021886300361003.

Minniti, M., \& Nardone, C. (2007). Being in someone else's shoes: the role of gender in nascent entrepreneurship. Small Business Economics, 28(2-3), 223-238. https://doi.org/10.1007/s11187-006-9017-y. 
Moore, D. P., \& Buttner, E. H. (1997). Women entrepreneurs: moving beyond the glass ceiling. California: Sage Publications.

Muchiri, M., \& McMurray, A. (2015). Entrepreneurial orientation within small firms: a critical review of why leadership and contextual factors matter. Small Enterprise Research, 22(1), 17-31. https://doi.org/10.1080 /13215906.2015.1017076.

Murphy, P. J. (2011). A $2 \times 2$ conceptual foundation for entrepreneurial discovery theory. Entrepreneurship Theory and Practice, 35(2), 359-374.

Ramos-Rodríguez, A. R., Medina-Garrido, J. A., Lorenzo-Gómez, J. D., \& Ruiz-Navarro, J. (2010). What you know or who you know? The role of intellectual and social capital in opportunity recognition. International Small Business Journal, 28(6), 566-582. https://doi.org/10.1177/0266242610369753.

Rauch, A., Wiklund, J., Lumpkin, G. T., \& Frese, M. (2009). Entrepreneurial orientation and business performance: an assessment of past research and suggestions for the future. Entrepreneurship Theory \& Practice, 33, 761-787.

Ringle, C. M., Wende, S. \& Becker, J. M. (2015). SmartPLS 3, Boenningstedt: SmartPLS GmbH. [online], http://www.smartpls.com.

Ripollés, M., \& Blesa, A. (2005). Personal networks as fosterers of entrepreneurial orientation in new ventures. The International Journal of Entrepreneurship and Innovation, 6(4), 239-248. https://doi. org/10.5367/000000005775179856.

Ruderman, M. P., Ohlott, K., Panzer, K., \& King, S. (2002). Benefits of multiple roles for managerial women. Academy of Management Journal, 45(2), 369-387. https://doi.org/10.2307/3069352.

Sánchez, J. C., Carballo, T., \& Gutiérrez, A. (2011). The entrepreneur from a cognitive approach. Psicothema, 23(3), 433-438.

Sánchez, J. (2013). The impact of entrepreneurship education program on entrepreneurial competencies and intention. Journal of Small Business Management, 51(3), 447-465. https://doi.org/10.1111/jsbm.12025.

Shane, S., \& Venkataraman, S. (2000). The promise of entrepreneurship as a field of research. Academy of Management Review, 25(1), 217-226.

Shane, S., Nicolaou, N., Cherkas, L., \& Spector, T. D. (2010). Do openness to experience and recognizing opportunities have the same genetic source? Human Resource Management, 49(2), 291-303. https://doi. org/10.1002/hrm.20343.

Taylor, M. P. (1996). Earnings, independence or unemployment: why become self-employed? Oxford Bulletin of Economics and Statistics, 58(2), 253-266.

Tenenhaus, M., Vinzi, V. E., Chatelin, Y. M., \& Lauro, C. (2005). PLS path modeling. Computational Statistics \& Data Analysis, 48(1), 159-205. https://doi.org/10.1016/j.csda.2004.03.005.

Venkataraman, S. (1997). The distinctive domain of entrepreneurship research. Advances in Entrepreneurship, Firm Emergence and Growth, 3(1), 119-138.

Wales, W. J., Gupta, V. K., \& Mousa, F. T. (2013). Empirical research on entrepreneurial orientation: an assessment and suggestions for future research. International Small Business Journal, 31(4), 357-383. https://doi.org/10.1177/0266242611418261.

Wilson, F., Kickul, J., \& Marlino, D. (2007). Gender, entrepreneurial self-efficacy, and entrepreneurial career intentions: implications for entrepreneurship education. Entrepreneurship Theory and Practice, 30(1), $387-406$.

Zahra, S. A., Korri, J. S., \& Yu, J. (2005). Cognition and international entrepreneurship: implications for research on international opportunity recognition and exploitation. International Business Review, 14(2), 129-114. https://doi.org/10.1016/j.ibusrev.2004.04.005.

Zahra, S. A., Sapienza, H. J., \& Davidsson, P. (2006). Entrepreneurship and dynamic capabilities: a review, model and research agenda. Journal of Management Studies, 43(4), 917-955. https://doi.org/10.1111 jj.1467-6486.2006.00616.x. 